7. Свербілова Т. Російська культура як «інший» у спадщині Миколи Хвильового та модель подолання окциденталізму у проекті Миколи Куліша // Слово і час. 2010. № 1. С.3-17.

8. Українка Леся. Зібрання творів у 12 т. / Леся Українка. К. : Наукова думка, 1975-1979. Т. 12.

9. Шевельов (Шерех) Ю.В. Я - мене - мені... (і довкруги): Спогади. В Європі. Т. 2. Харків, Нью-Йорк : Видання часопису «Березіль», Видавництво М.П. Коць, 2001. 304 с.

DOI https://doi.org/10.30525/978-9934-26-180-0-8

\title{
ТВОРЧІСТЬ Л. М. МОНТГОМЕРІ ТА ФЕМІНІЗМ
}

\author{
Козлова А. С. \\ магістр, викладач англійської мови та літератури, \\ начальник сектору міжнародного співробітництва \\ Головне управління Державної служби України з надзвичайних \\ ситуачій у Черкаській області \\ м. Черкаси, Україна
}

Дитинство канадійської письменниці Люсі Мод Монтгомері (1874 1942) вирізнялося переважно переживаннями самотності, замкнутості, усамітненості, адже мати померла, коли Люсі ще не виповнилося й 2 роки, а батька практичне вона не знала, бо він передав опіку над дитиною батькам покійної дружини. Письменниця згадує, що часто плакала й емоційну відраду знаходила в читанні. Перший роман письменниці «Енн із Зелених Дахів» (англ. Anne of Green Gables) порівнюють з історіями про подорожі Аліси $з$ легкої руки Марка Твена, який назвав Енн Ширлі найчудовішою дитиною від часів безсмертної Аліси [1]. До початку Першої світової війни Л. М. Монтгомері пише перші 6 книг серії про Енн Ширлі. Осмислення фінансового підтексту творчості у процесі боротьби за права, а також події Першої світової війни спричинили у письменниці тяжкий комплекс особистої провини, оскільки ії персональний гуманізм суперечив офіційному патріотизмові, тому іiі численні заклики до чоловіків іти на війну переживалися нею амбівалентно. Вона відчувала себе винною у смерті людей. Також на подальший аналіз ії творчості суттєво вплинули проблемні моменти іiі стосунків із чоловіком, які 
окреслили зміст моделей емоційного насильства над жінкою в родині у феміністичній критиці.

Творчість Л. М. Монтгомері часто розглядається у контексті ідей фемінізму. Відома канадійська письменниця М. Етвуд, яка належала до другої хвилі фемінізму (60 - 90-ті рр. XX ст.), наприкінці 80-х рр. «тлумачила творчість Монтгомері як щось більше, ніж просто дитяча художня література» чи жанрові твори комерційного спрямування. «Л. М. Монтгомері, і особливо ії персонаж Енн Ширлі, сприймалися як феміністичні героїні, випереджаючи свій час, представляючи рух, перш ніж з'явилася його назва», - пишуть сучасні дослідники [3]. Як зауважувала Ж. Х. Едельштайн уже у XXI ст. (2009), «ніколи це не було прямо сказано, але Енн, безумовно, феміністка, і бути феміністкою в Канаді початку XX ст. - це важкий шляХ» [1]. Також підкреслювалась увага письменниці до питань, сформульованих уже наприкінці XX ст., фемінізм і забобони, форми знущання та упослідження, бажання належати та бути вільною, проблематика гендерного аутсайдерства. Тобто, у творчості письменниці головну роль відіграє не соціальний аспект подолання нерівності між статями на законодавчому рівні, за що виступала перша хвиля фемінізму та рух суфражисток, а проблеми, пов'язані 3 фактичною нерівністю чоловіка і жінки в суспільстві, специфікою жіночої сексуальності, родиною, соціальним статусом на місці роботи та репродуктивними правами жінки. Можемо сказати, що авторка справді випередила формулювання цієї проблематики, оскільки в ії текстах, i насамперед у циклі про Енн Ширлі, уся ця проблематика присутня в імпліцитному вигляді, а деякі проблеми доволі широко експліковані, якот, наприклад, тема материнства, бездітності, репродуктивних прав жінки. При цьому слід зазначити, що атмосфера художнього всесвіту Монтгомері виключає вузько сектантський, задушливий підхід до осмислення питань гендеру. Ї̈̈ жінки живуть у чоловічому світі і навіть, зазнаючи в ньому страждань, не акцентують протиставлення жіночого і чоловічого та їх антагонізм, апелюючи до спільної людської природи та християнських цінностей, що їх об’єднують. Можна сказати, що образ жінки у Монтгомері як останній прихисток особистісної свободи зберігає власну гідність, нехай вразливу і не універсальну, але правдиву і нескорену. Як зазначає, коментуючи кореляцію гендеру 3 текстом, Ю. Крістева: «Вважати, що «ти» - жінка - майже не менше безглуздя та обскурантизм, ніж вважати, що «ти» - чоловік... жінкою не можна бути, бо жінка - це те, що навіть не доходить до буття. Отож на такій основі практика, яку здійснює жінка, може бути лише негативною, суперечити тому, що існує, щоб сказати: «Це не так» $\mathrm{i}$ «Цього ще немає». Отже, я розумію під 
«жінкою» те, що не репрезентується, те, що не висловлюється, лишаючись поза межами номінацій та ідеологій» [2, с. 456]. Подібний підхід [3] інтегрує за світоглядною ознакою творчість Л. М. Монтгомері до традиції другої хвилі феміністичної теорії і практики. Також зауважимо, що оскільки йдеться про твори традиційно тлумачені як такі, що належать до дитячої літератури, то форма виразу феміністичних ідей і власне їх репрезентація в сюжетах, побудові образів, діалогах зазвичай ніколи не $\epsilon$ прямою та не набуває плакатно-шаржевого характеру чи вигляду агітки. Художній світ письменниці надає цим ідеям об'єму та глибини, унеможливлюючи їх тлумачення за допомогою hate speech, мови ненависті та протистояння між статями. Крім того, не проводячи принципової відмінності між формами набуття досвіду у чоловіків і жінок, художній світ Монтгомері не може бути віднесений до третьої хвилі фемінізму, яка виходить 3 того, що існують нефіксовані, нестабільні квір-суб'єктивності як наслідок неоднорідності гендерних груп за ознаками класу, раси та сексуальності і відповідно нетотожності їхнього досвіду. Тобто, Монтгомері ніколи не переходить умовну точку перетину, за якою кількість відмінностей між гендерними групами перевищує кількість об'єднавчих факторів. На нашу думку, це робить її творчість такою привабливою для сучасного читача $\mathrm{i}$, що актуально, глядача (екранізації «Енн із зелених Дахів» - 1985, 1986, 2000; екранізації іншого романе - «Анна з Ейвонлі» 1989 - 1996, серіал СВС 1998 - 2000 «Емілі з Молодого Місяця» і останній серіал за мотивами серії 2017 - 2019 pp. виробництва Netflix) якраз тому, що вона аксіологічно монолітна, не підвладна негоції та фрагментарності постмодерної картини світу, а стверджує зрозумілі християнські цінності в нехай не надто простому світі. Інакше кажучи, ії книги, як і будь-які великі дитячі чи дорослі книги, надихають і дають сили жити. Подібний підхід [5] інтегрує за світоглядною ознакою творчість Л. М. Монтгомері до традиції другої хвилі феміністичної теорії і практики. Монтгомері ніколи не переходить умовну точку перетину, за якою кількість відмінностей між гендерними групами перевищує кількість об'єднавчих факторів. На нашу думку, це робить їі творчість такою привабливою для сучасного читача $\mathrm{i}$, що актуально, глядача (екранізації «Енн із зелених Дахів» - 1985, 1986, 2000; екранізації іншого романе - «Анна з Ейвонлі» 1989 - 1996, серіал СВС 1998 - 2000 «Емілі з Молодого Місяця» і останній серіал за мотивами серії 2017 - 2019 рр. виробництва Netflix) якраз тому, що вона стверджує зрозумілі християнські цінності в не надто простому світі. Інакше кажучи, iї книги, як і будь-які великі дитячі чи дорослі книги, надихають і дають сили жити. 


\title{
Література:
}

1. McIntosh, A., Devereux, C. Lucy Maud Montgomery. The Canadian encyclopedia. URL: https://thecanadianencyclopedia.ca/en/article/ montgomery-lucy-maud

2. Крістева Ю. Жінка ніколи не така. Ю. Крістева. Полілог. К. : Юніверс, 2004. 480 с. С. $454-460$.

3. Кретов П. В., Кретова О. І. Гендер, письмо та ідентичність: від фемінітиву до метафізики статі. Вісник Черкаського університету: Серія «Філософія». Наук. журнал. №2. Черкаси, 2017. С. 3 - 11.

DOI https://doi.org/10.30525/978-9934-26-180-0-9

\section{РЕПРЕЗЕНТАЦІЯ АНАЛІТИЧНОЇ МОДЕЛІ ХУДОЖНЬОГО ТЕКСТУ В РОМАНІ ДЖ. С. ФОЕРА «СТРАШЕННО ГОЛОСНО ТА НЕЙМОВІРНО БЛИЗЬКО»}

\author{
Кохан Р. А. \\ кандидат філологічних наук, \\ дочент кафедри іноземних мов для природничих факультетів \\ Львівський національний університет імені Івана Франка \\ м. Львів, Украӥна
}

Процес аналізу накладання та втілення художніх смислів літературного твору становить складну матрицю розпізнавання різновимірних кодів: авторська інтенція та читацькі очікування й настанови, рецептивна свідомість автора і читача, їхні емоційні максими під час співтворення художнього часопростору. Особливої якості ці передумови набувають 3 огляду на тенденції сучасного літературного процесу - «визначена невизначеність» тих характеристик, в ореолі яких дослідники конфронтують 3 проблемними питаннями щодо художнього твору, маркує гуманітарне сьогодення переважаючою стохастичністю. Постмодернізм, постпостмодернізм, метамодернізм - численні номінації та потреба влучних визначень, а, відтак, і точок опори, що відцентровуватимуть наукові прагнення, заводять дослідницький дискурс у філософсько-культурологічні лабіринти, що стирають усталені категоріальні межі і, відповідно, спричиняють множинні та щораз нові взаємодії та впливи.

Уведення структуралістських понять - «модель», «моделювання» - у дискурс феноменологічної, герменевтичної та рецептивної методології 38 